\title{
New RP-HPLC Method for the Quantification of Letrozole (An Anti-Cancer Agent)
}

\section{Mukthinuthalapati Mathrusri Annapurna*, Sistla Mounica Pratyusha and Raghu Raj Naik}

Department of Pharmaceutical Analysis and Quality Assurance GITAM Institute of Pharmacy, GITAM (Deemed to be University), Visakhapatnam, Andhra Pradesh, India.

*Corresponding Author: Mukthinuthalapati Mathrusri Annapurna, Department of Pharmaceutical Analysis and Quality Assurance GITAM Institute of Pharmacy, GITAM (Deemed to be University), Visakhapatnam, Andhra Pradesh, India.

Received: June 26, 2019; Published: July 22, 2019

DOI: $10.31080 /$ ASPS.2019.03.0348

\begin{abstract}
Letrozole is an oral non-steroidal aromatase inhibitor used for the treatment of cancer. A simple and new liquid chromatographic method has been developed for the assay of Letrozole tablets and the method was validated as per ICH guidelines. Shimadzu Model CBM-20A/20 Alite HPLC system equipped with PDA detector with C8 column ( $250 \mathrm{~mm} \times 4.60 \mathrm{~mm}$ i.d. $5 \mu \mathrm{m}$ particle size $)$ was used with a flow rate of $1.0 \mathrm{~mL} / \mathrm{min}$ (Detection wavelength $240 \mathrm{~nm}$ ). Letrozole has shown linearity 1-100 $\mu \mathrm{g} / \mathrm{mL}$ with linear regression equation $\mathrm{y}=93299 \mathrm{x}-2999.3\left(\mathrm{r}^{2}=0.9999\right)$. The LOD and LOQ were found to be $0.2799 \mu \mathrm{g} / \mathrm{ml}$ and $0.8691 \mu \mathrm{g} / \mathrm{ml} \mathrm{respectively.}$
\end{abstract}

Keywords: RP-HPLC; Letrozole; Assay; Validation; ICH Guidelines

\section{Introduction}

Letrozole is an anti-cancer agent especially used for the treatment of estrogen-dependent breast cancers [1]. Letrozole is chemically 4-[(4-cyanophenyl) - (1, 2, 4-triazol-1-yl) methyl] benzonitrile (Figure 1). It is is an oral non-steroidal aromatase inhibitor that has been introduced for the adjuvant treatment of hormonally-responsive breast cancer. It is readily and completely absorbed from the gastrointestinal tract. It is slowly metabolized in the liver to an inactive carbinol metabolite, which is then excreted as glucoronide in the urine [2]. Letrozole was determined by different analytical techniques such as Spectrophotometry [3,4], HPLC [512] in formulations and biological fluids and also with fluorescence detection [13], LC-MS [14] in human plasma and GC-MS [15] in urine and in the present study the authors have proposed a reverse phase isocratic liquid chromatographic method for the determination of Letrozole in tablets and the method was validated as per ICH guidelines [16].

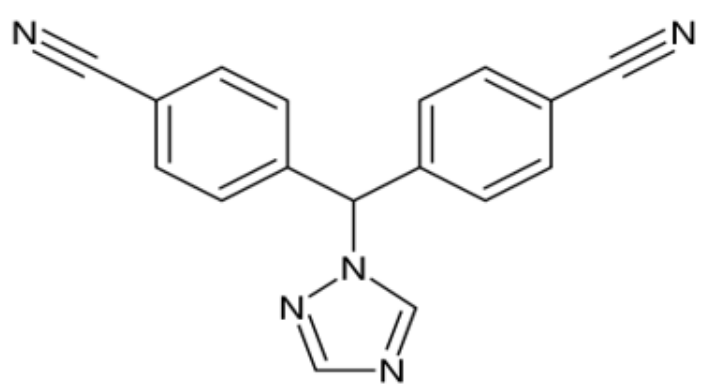

Figure 1: Chemical structure of Letrozole.

\section{Materials and Methods}

Instrumentation

Chromatographic separation was achieved by Shimadzu Model CBM-20A/20 Alite UFLC system (Shimadzu Co., Kyoto, Japan) equipped with SPD M20A prominence photodiode array detector 
on C18 column (250 $\mathrm{mm} \times 4.60 \mathrm{~mm}$ i.d. $5 \mu \mathrm{m}$ particle size) maintained at room temperature.

\section{Preparation of Letrozole drug solution}

$25 \mathrm{mg}$ of Letrozole was accurately weighed and dissolved in a $25 \mathrm{~mL}$ volumetric flask and volume was made up to the mark with HPLC grade acetonitrile $(1000 \mu \mathrm{g} / \mathrm{mL})$ and dilutions were made with mobile phase and filtered.

\section{Method validation}

Linearity, precision and accuracy

A series of solutions (1-100 $\mu \mathrm{g} / \mathrm{mL})$ of Letrozole were prepared from its stock solution, diluted with mobile phase and $20 \mu \mathrm{L}$ of each of these solutions were injected in to the HPLC system. The peak area of Letrozole was noted $(n=3)$ and the mean peak area was calculated from the chromatograms obtained and a calibration curve was drawn by taking the concentration of the Letrozole solutions on the $\mathrm{x}$-axis and the corresponding mean peak area values on the $\mathrm{y}$-axis.

Intraday and interday precision was studied on the same day and on three consecutive days respectively at three different concentration levels $(10,20$ and $50 \mu \mathrm{g} / \mathrm{mL})$ and the \% RSD was calculated. The accuracy of the assay method was evaluated in triplicate at three concentration levels $(50,100$ and $150 \%)$, and the percentage recoveries were calculated.

\section{Assay of letrozole tablets}

Letrozole is available in India as tablets with brand names FEMARA (Novartis), FERTOLET (Cipla Ltd.) and HERHOPE (Torrent Pharmaceuticals) with labelled claim $2.5 \mathrm{mg}$. The API of Letrozole was obtained as gift sample from Cipla Limited (India). Twenty tablets were procured, crushed and powdered. $25 \mathrm{mg}$ Letrozole tablet powder was extracted with acetonitrile and sonicated for half an hour and filtered through $0.45 \mathrm{~mm}$ membrane. Later suitable solutions were prepared on dilution with the mobile phase and $20 \mu \mathrm{L}$ of these solutions were injected in to the HPLC system and the peak area was noted along with the retention time from the resultant chromatogram and the percentage purity was determined from the linear regression equation.

\section{Results and Discussion}

A new reverse phase liquid chromatographic method was developed for the quantification of Letrozole tablets. Mobile phase composition acetic acid: acetonitrile: water (0.1: $50: 50 \mathrm{v} / \mathrm{v}$ ) with flow rate $1.0 \mathrm{~mL} / \mathrm{min}$ (UV detection at $240 \mathrm{~nm}$ ) for the determination of Letrozole. A sharp peak was observed at 3.403 min (Run time $10 \mathrm{~min}$ ) with all the system suitability parameters acceptance.
The theoretical plates were more than 2000 and the tailing factor was less than 1.5. The LOD and LOQ were found to be $0.2799 \mu \mathrm{g} /$ $\mathrm{ml}$ and $0.8691 \mu \mathrm{g} / \mathrm{ml}$ respectively. The chromatographic conditions (optimized) were shown in Table 1.

\begin{tabular}{|l|l|}
\hline Parameter & $\begin{array}{l}\text { Optimized chromatographic condi- } \\
\text { tions }\end{array}$ \\
\hline Mobile Phase & $\begin{array}{l}\text { Glacial acetic acid: Acetonitrile: Water } \\
(0.1: 50: 50)\end{array}$ \\
\hline Flow Rate & $1.0 \mathrm{~mL} / \mathrm{min}$ \\
\hline Detection wavelength & $240 \mathrm{~nm}$ \\
\hline Column temp. & $\left(25^{\circ} \pm 2^{\circ} \mathrm{C}\right)$ \\
\hline Injection Volume & $20 \mu \mathrm{L}$ \\
\hline Detector & $\begin{array}{l}\text { SPD M20A prominence photodiode ar- } \\
\text { ray detector }^{-}\end{array}$ \\
\hline Elution & Isocratic mode \\
\hline Total Run Time & 10 mins \\
\hline Retention time & 3.403 mins \\
\hline
\end{tabular}

Table 1: Optimized chromatographic conditions.

\section{Method validation}

Letrozole has shown linearity over the concentration range $1-100 \mu \mathrm{g} / \mathrm{mL}$ (Table 2) with linear regression equation $\mathrm{y}=93299 \mathrm{x}$ - $2999.3\left(R^{2}=0.9999\right)$ (Figure 2). The \% RSD was found to be 0.158 0.862 (Intraday) and 0.108-0.753 (Inter day) (Table 3) which is less than 2.0 stating that the method is precise. The \% recovery in accuracy study was found to be $99.52-99.67 \%$ (Table 4 ) and the \% RSD obtained was $0.253-0.491$ which is less than 2.0 stating that the method is accurate. The chromatograms obtained for Letrozole (API) was shown in Figure 3.

\begin{tabular}{|c|c|}
\hline Conc. $(\boldsymbol{\mu g} / \mathbf{m l})$ & Mean peak area \\
\hline 0 & 0 \\
\hline 1 & 93469 \\
\hline 5 & 467345 \\
\hline 10 & 934690 \\
\hline 20 & 1869382 \\
\hline 30 & 2804172 \\
\hline 40 & 3738530 \\
\hline 50 & 4583490 \\
\hline 60 & 5618444 \\
\hline 80 & 7457063 \\
\hline 100 & 9346903 \\
\hline
\end{tabular}

Table 2: Linearity of Letrozole.

*Mean of three replicates 


\begin{tabular}{|l|l|}
\hline \multirow{2}{*}{ Conc. $\boldsymbol{\mu g} / \mathbf{m l}$} & Interday precision \\
\cline { 2 - 2 } & * Mean \pm standard deviation (\% RSD) \\
\hline 10 & $935746.3 \pm 7046.1(0.753)$ \\
\hline 20 & $1871375.3 \pm 7204.7(0.385)$ \\
\hline 50 & $4674604.6 \pm 5048.5(0.108)$ \\
\hline & Intraday precision \\
\hline $10($ Day 1$)$ & $935746.3 \pm 1993.14(0.213)$ \\
\hline $10($ Day 2$)$ & $937862.3 \pm 4858.12(0.518)$ \\
\hline $10($ Day3) & $926951.3 \pm 7990.32(0.862)$ \\
\hline 20 (Day 1) & $1871375.3 \pm 6007.11(0.321)$ \\
\hline $20($ Day 2$)$ & $1864683.3 \pm 9360.71(0.502)$ \\
\hline 20 (Day 3) & $1879823.3 \pm 9192.33(0.489)$ \\
\hline 50 (Day 1) & $4674604.6 \pm 7385.87(0.158)$ \\
\hline 50 (Day 2) & $4575802.6 \pm 9975.24(0.218)$ \\
\hline 50 (Day 3) & $4551583.6 \pm 9012.13(0.198)$ \\
\hline
\end{tabular}

Assay of Letrozole tablets

Assay was performed by using two different brands of Letrozole tablets consisting of $2.5 \mathrm{mg}$ API and found that the amount of Letrozole was 99.28-99.88 (Table 5) and there is no interference of excipients (Figure 3 ).

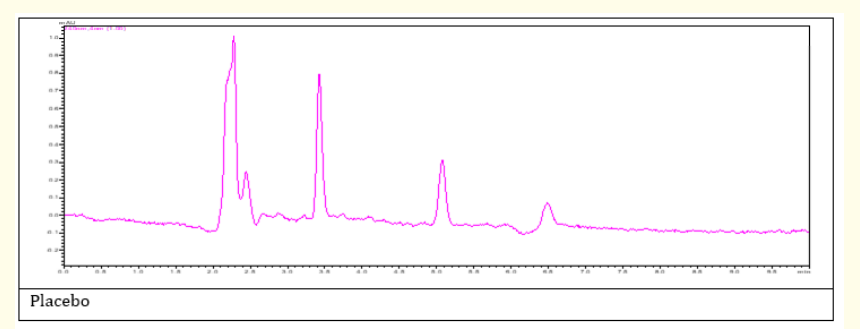

Table 3: Intraday precision study of Letrozole.

*Mean of three replicates

\begin{tabular}{|c|c|c|c|}
\hline $\begin{array}{l}\text { Spiked } \\
\text { Conc. } \\
(\mu \mathrm{g} / \mathrm{ml})\end{array}$ & $\begin{array}{c}\text { Formulation } \\
(\mu \mathrm{g} / \mathrm{ml})\end{array}$ & $\begin{array}{l}\text { Total } \\
\text { Conc. } \\
(\mu \mathrm{g} / \mathrm{ml})\end{array}$ & $\begin{array}{c}\text { *Conc. Obtained } \\
(\mu \mathrm{g} / \mathrm{ml}) \\
{[\% \text { Recovery] (RSD) }}\end{array}$ \\
\hline \multirow{3}{*}{$10(50 \%)$} & 20 & 30 & \multirow{3}{*}{$\begin{array}{c}29.857 \text { [99.52] } \\
(0.326)\end{array}$} \\
\hline & 20 & 30 & \\
\hline & 20 & 30 & \\
\hline \multirow{3}{*}{$20(100 \%)$} & 20 & 40 & \multirow{3}{*}{$\begin{array}{c}39.868 \text { [99.67] } \\
(0.491)\end{array}$} \\
\hline & 20 & 40 & \\
\hline & 20 & 40 & \\
\hline \multirow{3}{*}{$30(150 \%)$} & 20 & 50 & \multirow{3}{*}{$\begin{array}{c}49.829[99.66] \\
(0.253)\end{array}$} \\
\hline & 20 & 50 & \\
\hline & 20 & 50 & \\
\hline
\end{tabular}

Table 4: Accuracy study of Letrozole.

*Mean of three replicates
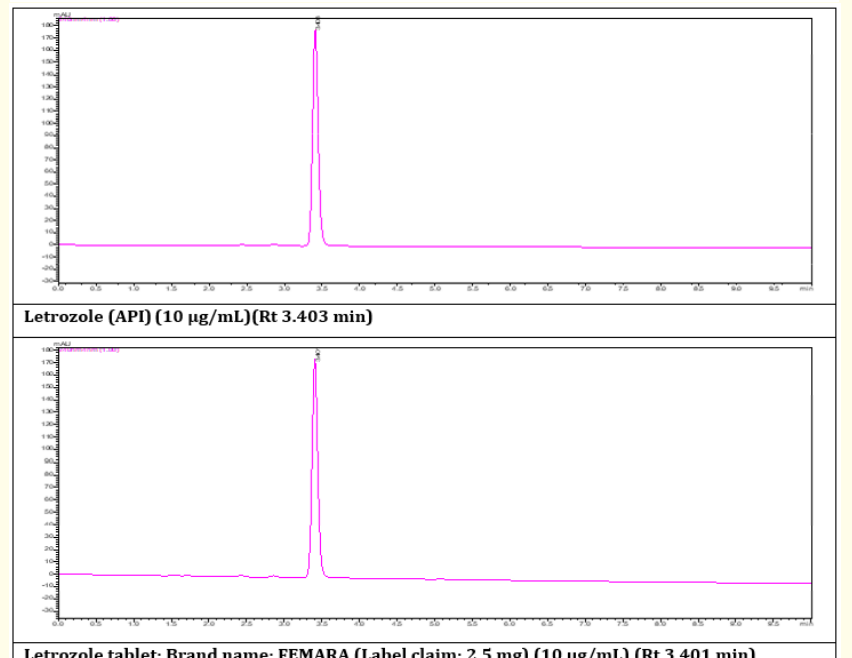

Letrozole tablet; Brand name: FEMARA (Label claim: $2.5 \mathrm{mg})(10 \mu \mathrm{g} / \mathrm{mL})(\mathrm{Rt} 3.401 \mathrm{~min})$

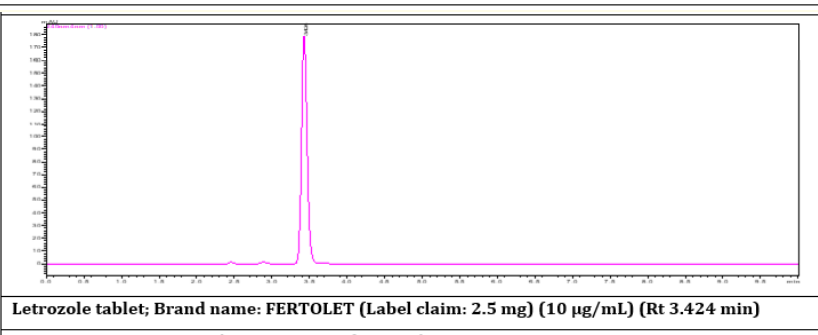

Figure 3: Representative chromatograms of Letrozole.

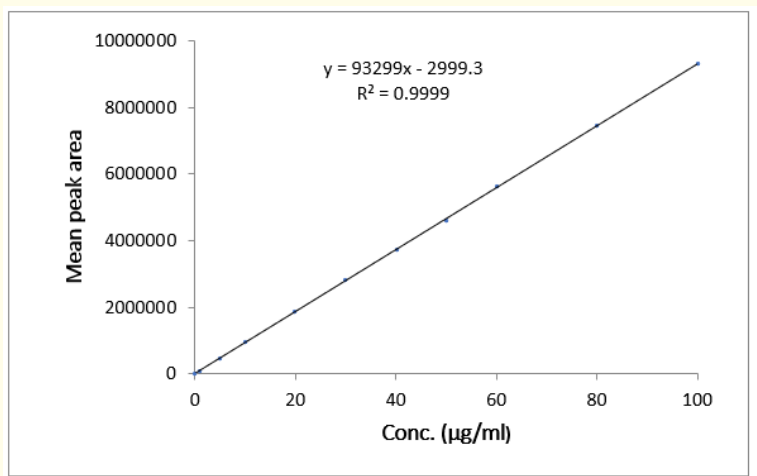

\begin{tabular}{|l|c|c|c|}
\hline Brand name & $\begin{array}{c}\text { Label claim } \\
\text { (mg) }\end{array}$ & $\begin{array}{c}\text { Observed amount } \\
\text { (mg) }\end{array}$ & $\begin{array}{c}\text { *Recovery } \\
\text { \% }\end{array}$ \\
\hline I & 2.5 & 2.493 & 99.72 \\
\hline II & 2.5 & 2.482 & 99.28 \\
\hline III & 2.5 & 2.497 & 99.88 \\
\hline
\end{tabular}

Table 5: Assay of Letrozole tablets.

*Mean of three replicates

\section{Conclusion}

The proposed liquid chromatographic method for the assay of

Figure 2: Calibration curve of Letrozole. Letrozole tablets was validated and the method is precise and accurate. There is no interference of the excipients. 


\section{Acknowledgement}

The authors are grateful to M/s GITAM (Deemed to be University), Visakhapatnam for providing the research facilities and Cipla Limited (India)for supplying gift samples of Letrozole. The authors declare no conflict of interest.

\section{Bibliography}

1. Iveson TJ., et al. "Phase 1 study of the oral non-steroidal aromatase inhibitor CGS 20267 in Healthy post-menopausal women". Journal of Clinical Endocrinology and Metabolism 77.2 (1993): 324-331.

2. Lamb HM., et al. "Letrozole a review of its use in post-menopausal women with advanced breast cancer". Drugs 56.6 (1998): 1125-1140.

3. Acharjya SK., et al. "Spectrophotometric methods for the determination of Letrozole in bulk and pharmaceutical dosage forms". Journal of Advanced Pharmacy and Technology and Research 1.3 (2010) 348-353.

4. Ganesh M., et al. "Validated UV spectrophotometric method for the determination of Letrozole in bulk and solid dosage form". Rasāyan Journal of Chemistry 1.1 (2008): 55-58.

5. Mathrusri Annapurna M., et al. "Stability-indicating liquid chromatographic method for the determination of Letrozole in pharmaceutical formulations". Journal of Pharmaceutical Analysis 2.4 (2012): 298-305.

6. Ganesh M., et al. "Determination of Letrozole in tablet formulations by reversed phase high performance liquid chromatography". Tropical Journal of Pharmaceutical Research 9.5 (2010): 505-510.

7. Anand S., et al. "Development of validated RP-HPLC method for determination of Letrozole in bulk and its pharmaceutical dosage forms". Der Pharmacia Sinica 2.2 (2011): 263-269.

8. Elkady EF., et al. "Preparation and characterization of two new forced degradation products of Letrozole and development of a stability-indicating RP-LC method for its determination". Pakistan journal of pharmaceutical sciences 28.6 (2015): 2041-2051.

9. Mondal N., et al. "Development and validation of RP HPLC method to determine Letrozole in different pharmaceutical formulations and its application to studies of drug release from nanoparticles". Acta Poloniae Pharmaceutica ñ Drug Research 66.1 (2009): 11-17.
10. Acharjya SK., et al. "Development of high- performance liquid chromatography for determination of Letrazole in wistar rat serum and its applications in Pharmacokinetic studies". Scientia Pharmaceutica 80.4 (2012): 941-953.

11. Sekar V., et al. "Bioanalytical method development and validation of Letrozole by RP-HPLC method". International Journal of Pharmaceutical Research and Development 1 (2009): 1-8.

12. Shervin PH., et al. "Synthesis and characterization of PEGylated dendrimers based on magnetic nanoparticles for Letrozole extraction and determination in body fluids and pharmaceutical samples". Microchemical Journal 143 (2018): 190-197.

13. Afshin Z., et al. "HPLC determination of Letrozole in plasma using fluorescence detection application to pharmacokinetic studies". Chromatographia 66.9-10 (2007): 747-750.

14. Chidambara J., et al. "Validation and application of a high performance liquid chromatography- tandem mass spectrometry assay for Letrozole in human plasma". Asian Journal of Pharmaceutical and Clinical Research 4.2 (2011): 107-112.

15. Mareck U., et al. "Identification of the aromatase inhibitor Letrozole in urine by gas chromatography / mass spectrometry". Rapid Communications and Mass Spectrometry 19.24 (2005): 3689-3693.

16. ICH Validation of analytical procedures: Text and methodology Q2 (R1), International Conference on Harmonization (2005).

Volume 3 Issue 8 August 2019

(C) All rights are reserved by Mukthinuthalapati

Mathrusri Annapurna., et al. 